\title{
Impact of Applying a Learning Strategy to Improve the Sample Quality in Cervical Screening in Nursing Staff in Social Service
}

\author{
Sandra Olimpia Gutiérrez Enríquez ${ }^{1}$ \\ Luis Fernando Méndez Donjuan² \\ Yolanda Terán Figueroa ${ }^{3}$ \\ Dario Gaytán Hernández ${ }^{4}$ \\ Cuauhtémoc Oros Ovalle ${ }^{5}$ \\ Aracely Díaz Oviedo ${ }^{6}$
}

\section{Impact of Applying a Learning Strategy to Improve the Sample Quality in Cervical Screening in Nursing Staff in Social Service}

Objective. The study sought to assess the impact of applying a learning strategy to improve the quality of sample collection during cervical screening by students from the Nursing Degree Program doing social service. Methods. This was a longitudinal, quasi-experimental study with the participation of 23 interns from the Nursing Degree Program at a public university from San Luis Potosí, Mexico. The work assessed knowledge of practical skills in taking cervical cytology tests and the quality of samples before and after applying a learning strategy that included $10 \mathrm{~h}$ of theoretical training and $22 \mathrm{~h}$ of practices on themes related to sample collection in cervical screening. Results. A statistically significant difference was obtained in improved knowledge $(t=-12.8 p<0.001)$ and practical skills $(t=-8.86 p<0.001)$ after the intervention. The increased percentage of suitable samples from $30.43 \%$ to $82.60 \%$ was attributed to the application of the learning strategy in the pre- and post-intervention phases $(p<0.001)$. Conclusion. Training is effective

\footnotetext{
1 Nurse, Ph.D. Professor, Universidad Autónoma de San Luis Potosí, México. email: sgutierr@uaslp.mx

2 Nurse, Masters. Hospital Central "Dr. Ignacio Morones Prieto”, San Luis Potosí, México. email: donjuanlf19@hotmail.com 3 Nurse, Ph.D. Professor, Universidad Autónoma de San Luis Potosí, México. email: yolandat@uaslp.mx

4 Computer Engineer, Ph.D. Universidad Autónoma de San Luis Potosí, México. email: dario.gaytan@hotmail.com

5 Medical Pathologist. Hospital Central “Dr. Ignacio Morones Prieto”. San Luis Potosí, México. email: cuoroso@hotmail.com 6 Nurse, Ph.D. Professor, Universidad Autónoma de San Luis Potosí, México. email: aracelydiaz21@hotmail.com
}

Article linked to research: Educational intervention in health staff in training to improve the quality in taking cervical cytology tests.

Conflict of interest: None

Received: October 27th 2016

Accepted: May 10th 2017

How to cite this article: Gutiérrez SO, Méndez LF, Terán Y, Gaytán D, Oros C, Díaz A. Impact of Applying a Learning Strategy to Improve the Sample Quality in Cervical Screening in Nursing Staff in Social Service. Invest. Educ. Enferm. 2017; 35(3): 340-347

DOI: 10.17533/udea.iee.v35n3a10 
to improve knowledge and practical skills to collect samples in cervical screening, as well as the quality of the samples for their interpretation.

Descriptors: uterine cervical neoplasms; Papanicolaou test; quality assurance; health care; inservice training; students, nursing.

\section{Impacto de la aplicación de una estrategia de aprendizaje para mejorar la calidad de la muestra en el tamizaje cervical en personal de enfermería en servicio social}

Objetivo. Evaluar el impacto de la aplicación de una estrategia de aprendizaje para mejorar la calidad de la toma de la muestra en el tamizaje cervical en estudiantes de Licenciatura de Enfermería en servicio social. Métodos. Estudio cuasi-experimental, longitudinal realizado en el que participaron 23 pasantes de la Licenciatura en Enfermería de una universidad pública de San Luis Potosí, México. Se evaluaron los conocimientos y las habilidades prácticas en la toma de las citologías cervicales y la calidad de las muestras antes y después de la aplicación de una estrategia de aprendizaje que incluía un entrenamiento de 10 horas teóricas y 22 horas prácticas con temas relacionados con la toma de muestra en el tamizaje cervical. Resultados. Se obtuvo una diferencia estadísticamente significativa en el mejoramiento de los conocimientos $(t=-12.8 p<0.001)$ y de las habilidades prácticas $(t=-8.86 p<0.001)$ después de la intervención. Se atribuyó a la aplicación de la estrategia de aprendizaje el aumento del porcentaje de muestras adecuadas de $30.43 \%$ a $82.60 \%$ en las fases de pre y post-intervención $(p<0.001)$. Conclusión. El entrenamiento es eficaz para mejorar los conocimientos y las habilidades prácticas para la toma de la muestra en el tamizaje cervical, así como la calidad de las muestras para su interpretación.

\section{Introduction}

Globally, cervical uterine (CU) cancer constitutes a public health problem, given that it causes 528 000 new cases and 270,000 deaths per year, with $85 \%$ of these occurring in developing countries. (1) In the last 30 years, incidence and mortality rates due to this type of cancer has diminished because social and economic indicators have
Descriptores: neoplasias del cuello uterino; prueba de Papanicolaou; garantía de la calidad de atención de salud; capacitación en servicio; estudiantes de enfermería.

\section{Impacto da aplicação de uma estratégia de aprendizagem para melhorar a qualidade da amostra na tamizagem cervical em pessoal de enfermagem no serviço social}

Objetivo. Avaliar o impacto da aplicação de uma estratégia de aprendizagem para melhorar a qualidade da toma da amostra na tamizagem cervical em estudantes de Licenciatura de Enfermagem no serviço social. Métodos. Estudo quase-experimental, longitudinal realizado com a participação 23 passantes da Licenciatura em Enfermagem de uma universidade pública de San Luis Potosí, México. Se avaliaram os conhecimentos as habilidades práticas na toma das citologias cervicais e a qualidade das amostras antes e depois da aplicação de uma estratégia de aprendizagem que incluía um treinamento de 10 horas teóricas e 22 horas práticas com assuntos relacionados com a toma de amostra na tamizagem cervical. Resultados. Se obteve uma diferença estatisticamente significativa no melhoramento dos conhecimentos $(t=-12.8 p<0.001)$ e das habilidades práticas $(t=-8.86 p<0.001)$ depois a intervenção. Se atribuiu à aplicação da estratégia de aprendizagem o aumento da porcentagem de amostras adequadas de $30.43 \%$ a $82.60 \%$ nas fases de pré e pós-intervenção $(p<0.001)$. Conclusão. 0 treinamento é eficaz para melhorar os conhecimentos e as habilidades práticas para a toma da amostra na tamizagem cervical, assim como a qualidade das amostras para sua interpretação.

Descritores: neoplasias do colo do útero; teste de Papanicolaou; garantia da qualidade dos cuidados de saúde; capacitação em serviço; estudantes de enfermagem.

improved. This change is due in great part to the implementation of secondary prevention efforts regarding early diagnosis and treatment of cancer precursor lesions during early stages. ${ }^{(2)}$ According to the Pan-American Health Organization in 2012 , over 83000 women were diagnosed with the disease and almost 36,000 died due to this cause in the Americas; adding that if current 
trends are manifested, the number of deaths will increase by $45 \%$ by 2030 . According to the same source, mortality rates are three times higher in Latin America and the Caribbean than in North America, revealing huge inequalities in health. ${ }^{(3)}$

In 2009, Mexico reported a mortality rate due to $\mathrm{CU}$ cancer of 9.1 cases per 100000 women and the state of San Luis Potosí reported 10.1 cases per 100 000 women. ${ }^{(4)}$ In this country, although screening is generally done by using the Papanicolaou test (cervical cytology or PAP), it is recognized that the effectiveness of the program on Timely Detection of Cervical Uterine Cancer has been poor. ${ }^{(5)}$ A critical element that explains the low impact of the program on mortality due to $\mathrm{CU}$ cancer in most Latin American countries is the dissociation between the screening and treatment activities, ${ }^{(6)}$ with one of the critical factors being the quality of the samples for screening due, among others, to lack of compliance with the guidelines established in the cytology and pathology manual regarding the revision of the cyto-colpo-histopathological congruence, forms of training, and quality control, as well as personnel deficiencies in sample collection. ${ }^{(7)} \mathrm{A}$ recent Mexican study ${ }^{(8)}$ showed that an important difficulty in the person collecting the sample is ignorance of the anatomy of the female lower genital tract, specifically the localization of the endocervix, the transformation zone, and lack of knowledge on which cells make up the transformation zone. Other faults were observed on the type of recommendations given to the user, the registry - particularly in identifying risk factors, and the gynecological evaluation before and during the test, as well as in applying the central technique (collecting the sample, spreading, and fixation).

The aforementioned justifies the need to conduct studies on educational interventions to improve the quality of sample collection from the cervical cytology. Students and interns (nursing staff engaged in social service) from the Nursing Degree Program in Mexico undertake their practices in public institutions. These practices include taking cervical cytology tests; hence, it is fundamental to improve capacities in this regard since their attendance to the university, which will increase their knowledge and skills as health service providers. Thus, the aim of this study was to evaluate the impact of applying a learning strategy to improve sample quality in cervical screening by the nursing staff in social service.

\section{Methods}

The study design was quasi-experimental, longitudinal and prospective, conducted in a university health center at a public university from February to June 2015. Convenience sampling was carried out of the institution where the study took place, with participation from 23 individuals who were about to complete their social service and required training in taking cervical cytology tests prior to concluding that stage. An educational intervention was designed based on the Andromache model for teaching innovation in taking these cytology tests, registered in the National Copyright Institute, dependent on the Mexican Secretary of Public Education (INDAUTOR, registry number: 032014-020412513001-01), and which was designed by researchers in the Faculty of Nursing at Universidad Autónoma de San Luis Potosí, Mexico. The intervention lasted two weeks with a total of $48 \mathrm{~h}, 24 \mathrm{~h}$ per week and was divided into three phases: 1- basal measurement, 2- training, and 3 -final measurement.

The first phase that conducted the basal measurement lasted $8 \mathrm{~h}$, considered for the study as the pre-intervention and it assessed knowledge on taking cervical cytology tests and the skill in its execution. To apply the intervention, personnel participated from Pathology, Nursing, Gynecology, specialists in public health and information technology, all trained and certified in their given area. Three instruments were used: a test to measure knowledge and two verification lists, one to evaluate skills in taking cytology tests and another to emit the report of the quality of the cervical cytology samples. Knowledge was measured by applying a structured survey with 57 items (scale from 0 - 57 points, starting from the Mexican official norm), which has four sections: personal data (6 items), Mexican Official Norm (NOM-014-SSA2-1994. Secretary of Health, 
Mexico) (four items); anatomy of the female lower genital tract (six items); and steps of the procedure to take cervical cytology tests (47 items).

To obtain the score in practical skills, a verification list was designed with a measurement scale from 0 to 126 points, with three codes to evaluate in the procedure to take the cervical cytology tests: 0 (not taken), 1 (partially taken), and 2 (taken). It has five sections: reception of the user (3 items), registries (23 items), preparation of material (2 items), preparation of the user ( 8 items), and screening technique (27 items). The highest score is 126 for the person who throughout the procedure obtained two points for each item. Quality of the cytology tests was obtained through the report from the pathologist who was considered the gold standard. This study catalogued as suitable those samples with endocervical cells. The results were reported in a verification list based on the Bethesda System 2001, which classifies the sample as suitable or unsuitable (Table 1). ${ }^{\left({ }^{9}\right.}$

Table 1. Bethesda System 2001. Quality classification of cervical cytology tests

\begin{tabular}{ll}
\hline \multicolumn{1}{c}{ Suitable sample } & \multicolumn{1}{c}{ Unsuitable sample } \\
Presence of 10 squamous cells of metaplasia & Shows $>75 \%$ necrosis \\
Presence of exocervix cells & Shows $>75 \%$ bleeding \\
Presence of cells from the transformation zone & Shows $>75 \%$ inflammation \\
Presence of 8,000 to 12,000 squamous epithelial cells & Shows $>75 \%$ poor fixation \\
\hline
\end{tabular}

Instrument reliability was measured through Cronbach's alpha $(0.74$ for the survey and 0.80 for the verification lists); experts on the topic provided validity.

The second phase corresponds to the training carried out during $32 \mathrm{~h}, 8 \mathrm{~h}$ per day. In this phase, theoretical classes (10 h) were dictated along with the practices ( $22 \mathrm{~h}$ ). The theory was taught by professors, physicians, and researchers who were experts on the topic, using reading material, videos on the correct taking of cervical cytology tests, systematization of experiences to obtain facilitators and hindrances from the opinions of the participants and based on their experience, didactic techniques, like plenary talks, expositions and demonstrations, such as the technique to carry out the staining train and the importance of correct sample taking. The core of this educational strategy is the practice phase, which applied innovative methodological strategies to propitiate a more significant learning environment. Among these is the in vivo reading of the cervical cytology samples, which means that once the participants collected the samples, the staining was done in the place where the course was being offered. Thereafter, during a special session, by using a microscope, the pathologist reads and interprets the samples in front of the participants. The pathologist interprets each sample and communicates to individuals the quality with which it was collected, indicating if the sample contains endocervical cells and emitting the diagnosis. To perform said activity, four real-situation practices were carried out with patients. The first is cataloged as the basal measurement or pre-intervention and the last as post-intervention, which were taken to make the final comparisons of this study. Additionally, two other intermediate practices were conducted, denominated 360-degree practices and pre-final evaluation. The first makes a paired assessment (two participants, one conducts the technique and the other evaluates it), this is done to reinforce learning. In addition, an evaluator or certified monitor is present and is always in the consultation rooms to assess the procedure.

The pre-final evaluation practice is considered the last opportunity to carry out the technique of 
taking the guided cervical cytology tests and with help from experts before the final evaluation. All the samples were collected with cyto-brush for endocervix and Ayre spatula for exocervix. The registry used a format denominated "Request and Results of Cervical Cytology" from the Secretary of Health in San Luis Potosí, Mexico. Other practices exist, like simulation and modelling. The first simulates taking cervical cytology tests by using lower mammal anatomical pieces (cow uterus) with simulator cytological models of flexible material with which students can improve their skills. Modelling is a workshop in which the participants use special soap to model their anatomical pieces (uterus and cervix) with which they perform the three central steps of this procedure: cell collection, spreading the cells on the sample holder, and fixation. Expert professors guide the practices at all times.

The final measurement ( $8 \mathrm{~h}$ ) constitutes the last phase and, for this study, it is called postintervention, which again and for the last time evaluated knowledge and practical skills. To analyze results related to knowledge and practical skills, Student's $t$ and the analysis of variance with repeated measures were applied. Analysis of the results of sample quality was done by using the binomial test.

This study kept in mind the ethical principles contained in the Helsinki declaration. All the participants and patients provided written informed consent. The Ethics Committee of the Faculty of Nursing and Nutrition at Universidad Autónoma de San Luis Potosí approved the project and assigned registry number CEIFE-2015-118. The diagnosis of the samples and their quality were validated through the Department of Pathology at Hospital Central Dr. Ignacio Morones Prieto located in the city of San Luis Potosí. All the results were delivered to the patients one month after performing the cytology study.

\section{Results}

This study showed in the participants a significant increase from the basal measurement to the final measurement in the average scores of theoretical knowledge (30.74 to 44.3 points) and in practical skills in taking cervical cytology tests (55.3 to 88.13 points) (Table 2).

A sustained increase was noted in the average score of practical skills measured during four sessions of the intervention $\left(1^{\text {st }}=55.34,2^{\text {nd }}=80.26,3^{\text {rd }}=\right.$ 84.78 , and $4^{\text {th }}=88.13$ ), showing in the ANOVA that differences were statistically significant only between the first and the remaining three (Table 3).

The pre-intervention reported $30.43 \%$ suitable samples versus $82.6 \%$ in the post-intervention; this difference was statistically significant ( $p=$ $<0.001$ ) (Table 4).

Table 2. Scores of knowledge and practical skills for cervical screening $(n=23)$

\begin{tabular}{llcccc}
\hline \multirow{4}{*}{ Variable } & Statistics & Pre-intervention & Post-intervention & Difference & $\boldsymbol{p}$ \\
\cline { 3 - 3 } Knowledge & Median & 30.74 & 44.39 & -13.65 & \\
& SD* & 5.387 & 3.026 & 5.11 & $<0.001$ \\
& Minimum & 21 & 40 & -15 & \\
\multirow{4}{*}{ Skills } & Maximum & 39 & 50 & -11 & \\
& Median & 55.35 & 88.13 & -32.78 & $<0.001$ \\
& SD & 17.644 & 3.252 & 17.740 & \\
& Minimum & 21 & 79 & -40 & \\
\hline
\end{tabular}

$\left({ }^{*}\right)$ Standard deviation 
Table 3. Results of the ANOVA of repeated measurements of the comparison of skills among practice sessions $(n=23)$

\begin{tabular}{cccccc}
\hline Practice & Measurements & $\begin{array}{c}\text { Difference of } \\
\text { means }\end{array}$ & $\begin{array}{c}\text { Lower } \\
\text { limit }\end{array}$ & $\begin{array}{c}\text { Upper } \\
\text { limit }\end{array}$ & $\boldsymbol{p}$ \\
& 2 & -24.91 & -35.35 & -14.46 & $<0.001$ \\
& 3 & -29.43 & -40.52 & -18.34 & $<0.001$ \\
& 4 & -32.78 & -43.50 & -22.06 & $<0.001$ \\
& 1 & 24.91 & 14.46 & 35.35 & $<0.001$ \\
& 3 & -4.52 & -10.58 & 1.54 & 0.251 \\
3 & 4 & -7.87 & -13.61 & -2.12 & 0.004 \\
& 1 & 29.43 & 18.34 & 40.52 & $<0.001$ \\
& 2 & 4.52 & -1.54 & 10.58 & 0.251 \\
4 & 4 & -3.34 & -7.09 & 0.39 & 0.100 \\
& 1 & 32.78 & 22.06 & 43.50 & $<0.001$ \\
& 2 & 7.87 & 2.12 & 13.61 & 0.004 \\
& 3 & 3.34 & -0.39 & 7.09 & 0.100 \\
\hline
\end{tabular}

Table 4. Pre- and post-intervention report of sample quality $(n=23)$

\begin{tabular}{ccccc}
\hline \multicolumn{1}{c}{ Practice } & \multicolumn{2}{c}{ Suitable } & \multicolumn{2}{c}{ Unsuitable } \\
& Number & $\%$ & Number & $\%$ \\
Pre-intervention & 7 & 30.43 & 16 & 69.56 \\
Post-intervention & 19 & 82.60 & 4 & 17.39 \\
\hline
\end{tabular}

\section{Discussion}

This study revealed that in the basal measurement participants obtained a low score with respect to the expected score. This result agrees with that reported by Songthap et al., ${ }^{(10)}$ Arias et al., ${ }^{(11)}$ and Makwe et al.,(12) who found that students demonstrated medium knowledge on CU cancer, given that they lacked sufficient clarity on the theme. Weaknesses found in this study regarding the low knowledge of the participants is related to the results of the samples in function of the quality reported through pathology because the first measurement only obtained $30.43 \%$ of samples with optimal quality and with the presence of endocervical cells. This result is similar to that reported by Yoshino et al., ${ }^{(13)}$ whose work with nurses from a university in Japan indicates that only $4.7 \%$ knew that CU cancer is detected through tests, like the Papanicolaou test, and concludes that deficient knowledge in this staff was associated with the failure to undergo cancer detection. Likewise, the study by Ali et al.,(14) 2010, with interns in social service and nursing staff from a tier III hospital in Karachi, Pakistan, also indicates that only $23.3 \%$ were aware that $\mathrm{CU}$ cancer is the most common cause among gynecological cancers and $41 \%$ ignored the new detection methods; concluding that most service providers do not have sufficient knowledge on this ailment.

During post-intervention, the participants improved notably in knowledge acquisition and improved their practical skills, gained greater confidence, and the guidance provided to users was better. In this evaluation, the mean score in practical skills improved compared to the first measurement in the five sections assessed 
(from 55.35 to 88.13 points). This result was reflected in the pathology report during the postintervention, given that it reported $80 \%$ suitable samples, with useful material for its interpretation, which was the main objective in this study. This agrees with the results by Gómez et al.., ${ }^{(15)}$ where after an educational intervention to improve the taking of cervical cytology tests, it reported a greater amount of cervical material useful to emit results that are more accurate and diminish false negatives.

Training with this innovative methodology is effective to increase the capacities of participants, as well as to improve the quality of the samples from cervical cytology tests, given that this training has implemented strategies different from the habitual strategies. Nevertheless, it is fundamental to continue improving the teaching methodologies in students and health professionals. It is important to reinforce general learning in taking cervical cytology tests in the following aspects: awareness of the anatomical characteristics of a cervix, the way of conducting the gynecological assessment, different instruments used to collect samples, and the correct fixation technique.

One of the limitations in this study was the availability of educational and health institutions to allow their interns in social service to attend the training. We recommend increasing the number of participants in applying this methodology, as well as measuring the variables one or six months after the training concludes. We also recommend using this model in other intervention scenarios and testing new "be learning"-type tools to implement the advanced technology in health education.

In conclusion, interns in social service have among their functions that of providing care in public health services, and to a large extent, performing cervical screening, which is why it is fundamental for them to have solid theoretical and practical training that integrates the capacities and skills requested by the labor setting. Thus, upon increasing their technical skills and knowledge on cervical cancer, they will enhance their practice along with the quality of public services. This study identified the importance of continuous training of the health staff in formation, given that during their attendance in the university, they acquire the necessary theoretical knowledge, but often practice is minimal in relation to the opportunities of direct care to patients. The results from this study evidence the need to implement continuous training and updating of the health staff, as indicated in the NOM-014SSA2-1994 standard, for prevention, detection, diagnosis, treatment, control, and epidemiological surveillance of cervical-uterine cancer, as well as by the Action Program on Cervical Cancer in Mexico 2007-2012.

\section{References}

1. Organización Panamericana de la Salud/ Organización Mundial de la Salud. Cáncer Cervicouterino [Internet]. [cited 2017 Aug 17]. Available from: http://www.paho.org/hq/index. php?option $=$ com_content\&view $=$ article\&id $=542$ 0\%3A2011-cervical-cancer\&catid $=1872 \% 3 \mathrm{Aca}$ ncer\&ltemid $=3637$ \&lang $=$ es

2. Organización Mundial de la Salud. Control integral del cáncer cervicouterino: Guía de prácticas esenciales [Internet]. Ginebra: OMS; 2016 [cited 2017 Aug 17]. Available from: http://iris.paho.org/xmlui/bitstream/hand le/123456789/31403/9789275718797-por. pdf? sequence $=1$ \&isAllowed $=\mathrm{y}$

3. Globocan 2012: Estimated cancer incidence, mortality and prevalence worldwide in 2012. Geneve: IARC, WHO; 2016 [cited 2017 Aug 17]. Available from: http://gco.iarc.fr/today/onlineanalysis-map? mode $=$ population\&mode_populat ion $=$ continents $\&$ population $=900 \&$ sex $=2 \&$ canc er $=16 \&$ type $=0 \&$ statistic $=0 \&$ prevalence $=0 \& \mathrm{col}$ or_palette $=$ default\&projection $=$ globe

4. Instituto Nacional de Estadística y Geografía e Informática (INEGI). México: Gobierno Federal; 2012.

5. Hernández-Avila M, Lazcano-Ponce E, Martínez $\mathrm{O}$. Public policies for HPV screening and vaccination in Mexico. In the 27th International Papillomavirus Conference and Clinical Workshop. September 17-23, Berlin, Germany; 2011.

6. Wiesner C, Cendales R, Murillo R, Piñeros M, Tovar S. Seguimiento de mujeres con anormalidad citológica de cuello uterino en Colombia. Rev. Salud Pública. 2010; 12(1):1-13. 
7. Secretaría de Salud, México. Programa de acción específico 2007-2012. Cáncer cervical [Internet]. Secretaría de Salud: México; 2013 [cited 2017 Aug 17]; Available from: http://www.cnegsr.salud. gob.mx/contenidos/descargas/CaCu/pae_cacu.pdf

8. Gutiérrez-Enríquez SO, Frías-Navarro V̄o, OrosOvalle C, Ortiz-Valdez JA, Gaytán-Hernández D, Terán-Figueroa Y. Training of health personnel to improve knowledge and skills in taking Pap: Effect of an educational intervention to prevent cervical cancer. Health. 2013; 5(7D):60-4.

9. Solomon D, Davey D, Kurman R, Moriarty A, O'Connor D, Prey M, et al. The 2001 Bethesda System: Terminology for Reporting Results of Cervical Cytology. JAMA. 2002; 287(6):2114-9.

10. Songthap A, Pitisuttithum P, Kaewkungwal J, Fungladda W, Bussaratid V. Knowledge, attitudes, and acceptability of a human papilloma virus vaccine among students, parents and teachers in Thailand. Southeast Asian J. Trop. Med. Public Health. 2012; 43:340-53.

11. Arias ML, Pineda SA. Conocimientos que tienen los estudiantes de una universidad pública de
Manizales sobre el papiloma virus humano. Hacia la Promoción de la Salud. 2011, 16(1):110-23.

12. Makwe CC, Anorlu RI. Knowledge of and attitude toward human papillomavirus infection and vaccines among female nurses at a tertiary hospital in Nigeria. International journal of women's health. 2011; 3:313-17.

13. Yoshino $Y$, Ohta $H$, Kawashima M, Wada K, Shimizu M, Sakaguchi H, Aizawa Y. The knowledge of cervical cancer and screening adherence among nurses at a university-affiliated hospital in Japan. Kitasato Med. J. 2012: 20(29):6-14.

14. Ali SF, Ayub S, Manzoor NF, Azim S, Afif M, Akhtar N, Uddin N. Knowledge and awareness about cervical cancer and its prevention amongst interns and nursing staff in Tertiary Care Hospitals in Karachi, Pakistan. PlosONE. 2010; 5(6): e11059.

15. Gómez M, Díaz I, Quiroz PS, Olvera RA, De la Rosa MV. Evaluación de una intervención educativa en la mejora del procedimiento para DOC. Rev. Enferm. IMSS. 2002; 10:137-44. 